\title{
Management of Daylily Rust with Different Fungicides and Application Methods
}

W. B. Dong, Department of Plant Pathology, University of Georgia, Griffin, GA 30223; S. N. Jeffers, School of Agricultural, Forest, and Environmental Sciences, Clemson University, Clemson, SC 29634; and J. W. Buck, Department of Plant Pathology, University of Georgia, Griffin, GA 30223

\begin{abstract}
Dong, W. B., Jeffers, S. N., and Buck, J. W. 2013. Management of daylily rust with different fungicides and application methods. Plant Dis. 97:921926.

The objectives of this study were to assess the efficacy of various fungicides applied as root dips, soil drenches, or foliar sprays to daylily plants grown in containers and planted in the field to manage rust caused by Puccinia hemerocallidis. Soil drenches and foliar sprays were evaluated in field experiments in Griffin, GA in 2010 and 2011. Dipping bare-root daylily plants for $5 \mathrm{~min}$ in azoxystrobin, tebuconazole, or thiophanate-methyl significantly reduced lesion development compared with nontreated control plants. Drenches with azoxystrobin, fluoxastrobin, or tebuconazole, each at three rates $(0.06,0.12$, and 0.24

$\mathrm{g}$ of active ingredient [a.i.]/container), significantly reduced development of rust lesions on container-grown daylily plants for up to 9 weeks after treatment and 6 weeks after inoculation. One early-season drench of azoxystrobin at $0.12 \mathrm{~g}$ a.i../plant provided season-long reduction in disease incidence and disease progress that was comparable with foliar sprays with azoxystrobin or chlorothalonil applied at 14-day intervals. Dip or drench applications of fungicides would allow growers to diversify rust management options and could reduce the number of foliar fungicide applications.
\end{abstract}

Daylily plants (Hemerocallis spp.) are herbaceous, perennial plants that are native to Eurasia, including the countries of China, Korea, and Japan. These plants are popular worldwide and are used extensively in landscapes (8). Daylily rust, caused by Puccinia hemerocallidis Thüm., has been present in North America for over a decade (26). Daylily rust can negatively affect the production, distribution, sales, and cultivation of daylily plants in the United States because infected plants often are not marketable. Commercial production of daylily includes plants grown in containers of soilless media or plants grown in soil in the field. Field-grown plants then are dug and placed into containers or are kept as bareroot plants (i.e., roots minus soil, with some foliage removed). Long-distance movement of daylily rust throughout North America has occurred primarily due to interstate movement of infected plants and propagation stock (4).

Exclusion of the pathogen is one of the most effective management strategies for plant diseases. However, if daylily rust already is present and the risk of infection is high, growers rely on fungicides for management of the disease. Several fungicides provide excellent control of daylily rust when used as foliar sprays $(5,6,14)$. For example, in a greenhouse study, azoxystrobin, chlorothalonil, myclobutanil, propiconazole, and triadimefon significantly reduced lesion development by $P$. hemerocallidis on daylily when applied 15 days prior to inoculation (14). Pyraclostrobin significantly reduced lesion development by $P$. hemerocallidis on potted plants treated with the fungicide 21 days prior to inoculation (6).

In addition to foliar applications, a fungicide suspension can be used to wet the root zone of established plants (soil drenches) or as a dip solution for propagation units such as corms, bulbs, or bare root plants (root dips). Fungicide dips or drenches typically target

Corresponding author: J.W. Buck, E-mail: jwbuck@uga.edu

Current address of W. B. Dong: Seminis Seeds (Beijing) Shandong R\&D Station, Xinzhao village, Song Zhuang Town Changyi City Shandong Province, 261314, P.R. China.

Accepted for publication 18 January 2013.

http://dx.doi.org/10.1094/PDIS-12-12-1127-RE

(C) 2013 The American Phytopathological Society soilborne pathogens such as species of Fusarium or Phytophthora $(9,11,18)$. The effect of fungicide drenches on foliar diseases is less well known. Drench applications of tebuconazole reduced black spot on rose plants in field trials $(10 ; \mathrm{S}$. N. Jeffers, unpublished data). We observed that a high, non-label rate $(0.125$ to $0.5 \mathrm{~g}$ of active ingredient [g a.i.]/pot) drench application of azoxystrobin, myclobutanil, or tebuconazole significantly reduced lesion development by $P$. pelargonii-zonalis on potted geranium (20).

Effective fungicide dips on bare-root plants or drenches to container-grown plants in greenhouses and nurseries would reduce the potential risk of moving daylily rust on infected plants. Drench applications in field plantings and the landscape should reduce the number of foliar sprays needed to manage rust. Therefore, the objective of this study was to compare the efficacies of various fungicides applied as root dips, soil drenches, or foliar sprays to manage daylily rust on container- and field-grown daylily plants.

\section{Materials and Methods}

Greenhouse experiments. All trials were conducted on the highly susceptible Hemerocallis 'Pardon Me'. Bare-root daylily plants were obtained from a commercial grower and potted in a soilless medium (Metro-Mix 400; The Scotts Company) in 5.7-liter containers with one plant per container. Plants were irrigated as needed and fertilized with Osmocote Plus 15-9-12 (The Scotts Co.) controlled-release fertilizer. Isolate Grif 2 of $P$. hemerocallidis (7) was maintained on daylily Pardon Me plants in a greenhouse with average day and night temperatures of 24 and $22^{\circ} \mathrm{C}$, respectively. Fresh urediniospores were collected for each experiment from sporulating pustules using a vacuum spore collector (16). Urediniospores were suspended at $1 \times 10^{5}$ urediniospores $\mathrm{ml}^{-1}$ in $0.05 \%$ Tween 20 (J. T. Baker) and used to inoculate daylily plants. Plants were watered immediately prior to inoculation, sprayed until runoff with the urediniospore suspension using a hand-held sprayer, placed in plastic bags to maintain high relative humidity, and stored in the dark at $22^{\circ} \mathrm{C}(16)$. Plants were removed from bags after $24 \mathrm{~h}$ and moved to a greenhouse. Fungicides (Table 1) were tested by mixing specified amounts of commercial products in a standard volume of distilled water; fungicide rates are expressed as concentrations of active ingredients. All experiments were arranged in a randomized complete block design with replicate four plants (pots) in each treatment. Disease severity was assessed using a 0to- 5 rating system based on the percentage of each leaf covered by lesions, where $0=$ no lesions and $1=$ less than $5,2=5$ to $10,3=$ 
10 to $25,4=25$ to 50 , and $5=$ over $50 \%$ of each leaf covered by lesions. A disease severity index (DSI) was calculated for each plant using the formula DSI $(\%)=\left(\Sigma n_{i} \times i\right) /(5 \times N) \times 100$, where $i$ is rust severity value ( 0 to 5 ), $n_{i}$ is the number of leaves with the value of $i$, and $N$ is the total number of leaves evaluated on each plant $(13,22)$. DSI data for each evaluation period (i.e., 6 and 9 weeks after treatment) were analyzed separately by one-way analysis of variance (ANOVA) using the general linear models procedure (PROC GLM) of SAS, version 9.2 (SAS Institute). Means were separated by Fisher's protected least significant difference (LSD) with $P=0.05$.

Root dips in fungicides. Dip treatments in $\mathrm{NaClO}$ and three concentrations of six fungicides-azoxystrobin, chlorothalonil, fludioxonil, mancozeb, tebuconazole, and thiophanate-methylwere evaluated for the ability to reduce subsequent rust development. Infected plants were harvested from field plots, soil was removed from the roots by gentle agitation in water, and the outer leaves were stripped and discarded. Roots of each bare-root plant were dipped in $0.525 \% \mathrm{NaClO}$ ( 1 part commercial bleach to 9 parts water) or in fungicides at $2.4 \mathrm{~g}$ a.i. liter $^{-1}$ for $5 \mathrm{~min}$, air dried, and then replanted in 5.7-liter containers. Containers were placed on a greenhouse bench. Plants were enclosed in plastic bags overnight every 2 weeks to promote infection. Plants were irrigated as needed and fertilized with Osmocote Plus 15-9-12 controlled-release fertilizer. Disease was assessed 6 and 9 weeks after treatment based on previous work with geranium rust (20), and DSIs were calculated as described above. Plants were observed weekly for phytotoxicity. The experiment was repeated.

Soil drenches with fungicides. Four fungicides were evaluated using a soil drench application: azoxystrobin, fluoxastrobin, myclobutanil, and tebuconazole (Table 1). The root zones of rustfree daylily plants were drenched with each fungicide at three rates: $0.06,0.12$, and $0.24 \mathrm{~g}$ a.i./container in $200 \mathrm{ml}$ of water. Water was used to drench plants in the nontreated control treatment. Leaves were marked before treatment to differentiate between new and old growth. Three weeks after treatment, all plants were inoculated with urediniospores of $P$. hemerocallidis as described above. Fungicide-drenched plants were observed for phytotoxicity every day after treatment. Data on rust severity and numbers of new leaves were collected 3 and 6 weeks after inoculation (i.e., 6 and 9 weeks after treatment). Rust severity data were converted to DSI as described above. The experiment was repeated. Data for each evaluation period (i.e., 6 and 9 weeks after treatment) were analyzed separately. Data for all five treatments were analyzed by twoway ANOVA to identify main effects of fungicide and rate and to determine whether there was a significant interaction between these two factors. Because the interaction was significant, one-way ANOVA was used to identify the simple effect of rate for each of the individual fungicides. Means were separated by LSD with $P=$ 0.05 .
Fungicides applied to field-grown plants. Field trials were conducted in 2010 and 2011 at the Griffin Campus of the University of Georgia in Griffin on Cecil sandy clay loam ( $\mathrm{pH} 6.2,1.9 \%$ organic matter). In all, 225 bare-root daylily (Pardon Me) plants obtained from a commercial grower were transplanted in 25 rows at $0.9-\mathrm{m}$ spacing with 9 plants per row (at $0.6-\mathrm{m}$ intervals) in early spring 2010. The entire study area was covered with 5 to $10 \mathrm{~cm}$ of pine bark mulch. Plants were irrigated as needed and fertilized with 10-10-10 soluble fertilizer (Farmer Favorite Fertilizer) at 5.7 $\mathrm{kg} \mathrm{ha}^{-1}$ every 2 months. In April 2010, rust was introduced into the field on 10 diseased plants that had been inoculated in the greenhouse. Diseased plants were evenly spaced throughout the planting site. $P$. hemerocallidis that overwintered in the field produced the primary inoculum (urediniospores) that initiated disease in 2011. Label rates of azoxystrobin (0.04 $\mathrm{g}$ a.i./plant), chlorothalonil (0.78 $\mathrm{g}$ a.i./plant), myclobutanil (0.01 g a.i./plant), and tebuconazole (0.03 g a.i./plant) were applied as foliar sprays. Two nickel treatments (Nickel Plus; Nipan LLC) also were included and were applied as foliar sprays (19): nickel alone (0.01 g a.i./plant) and nickel combined with chlorothalonil (nickel at $0.01 \mathrm{~g}$ a.i./plant and chlorothalonil at $0.78 \mathrm{~g}$ a.i./plant). A single soil drench treatment with azoxystrobin (0.12 g/a.i./plant) or tebuconazole $(0.06 \mathrm{~g}$ a.i./plant) was applied each year, on 2 June 2010 and 6 June 2011, using $500 \mathrm{ml}$ of water for each plant. A nontreated block of plants was used as a control treatment. Each treatment plot consisted of three plants in a row. The plots were arranged in a randomized complete block design with blocks replicated four times. Spray treatments were initiated on 14 June each year, with subsequent applications made on a 14-day schedule. Each spray treatment was on a cycle that consisted of two applications of the test fungicide followed by an application of chlorothalonil. Chlorothalonil was used to simulate a fungicide rotation with different active ingredients to reduce the potential for the development of fungicide resistance building in the target population. One spray cycle covered 42 days (i.e., 14, 14, $14=42$ days). Treatments were continued for three spray cycles without the final spray of chlorothalonil. For example, the azoxystrobin spray treatment consisted of six applications of azoxystrobin and two applications of chlorothalonil. All fungicide spray treatments were applied with a $\mathrm{CO}_{2}$-pressurized (276 kPa) backpack sprayer using a single flat-fan air-induction nozzle (11002VS; TeeJet Technologies). A volume of 500 to 1,000 $\mathrm{ml}$ of fungicide was applied to each block of three daylily plants. The volume of fungicide solution required to wet the foliage in each block increased as the plants got larger through the season. Rust was assessed weekly from the first appearance of symptoms in the field, from 2 August to 8 November 2010 and 18 July to 14 October 2011. Disease severity was assessed with a 0-to-5 rating system, where $0=$ no lesions, $1=$ few lesions on old leaves, $2=$ many lesions on old leaves, 3 = few lesions on new leaves, $4=$ many lesions on new leaves, and $5=$ many lesions on every leaf.

Table 1. Fungicides applied to daylily plants to manage daylily rust

\begin{tabular}{|c|c|c|c|c|c|}
\hline Active ingredient & Chemical category & Trade name & $\begin{array}{l}\text { FRAC } \\
\text { code }^{y}\end{array}$ & Formulation $^{z}$ & Company \\
\hline Azoxystrobin & Quinone outside inhibitor (QoI) & Heritage & 11 & $50 \mathrm{WDG}$ & Syngenta Crop Protection Inc., Greensboro, NC \\
\hline Chlorothalonil & Broad-spectrum protectant & Daconil Ultrex & M5 & $82.5 \mathrm{WDG}$ & Syngenta Crop Protection \\
\hline Fludioxonil & Phenylpyrrole & Medallion & 13 & $50 \mathrm{WP}$ & Syngenta Crop Protection \\
\hline Fluoxastrobin & QoI & Disarm 480 & 11 & $40.3 \mathrm{SC}$ & $\begin{array}{l}\text { Arysta LifeScience North America LLC, } \\
\text { Mainland, PA }\end{array}$ \\
\hline Flutolanil & Succinate dehydrogenase inhibitor & Contrast & 7 & $70 \mathrm{WSP}$ & $\begin{array}{l}\text { Scotts-Sierra Crop Protection Company, } \\
\text { Marysville, OH }\end{array}$ \\
\hline Mancozeb & Dithiocarbamate & Dithane $\mathrm{T} / \mathrm{O}$ & M3 & 75 WDG & DOW Agrosciences LLC, Indianapolis, IN \\
\hline Myclobutanil & Demethylation inhibitors (DMI) & Eagle & 3 & $20 \mathrm{EW}$ & DOW Agrosciences LLC \\
\hline Propiconazole & DMI & Banner MAXX & 3 & 14.3 MEC & Syngenta Crop Protection \\
\hline Tebuconazole & DMI & $\begin{array}{l}\text { Lynx } \\
\text { Torque }\end{array}$ & 3 & $\begin{array}{l}22 \mathrm{SC} \\
38.7 \mathrm{SC}\end{array}$ & $\begin{array}{l}\text { Bayer Crop Science, Research Triangle Park, NC } \\
\text { Cleary Chemical Corporation, Dayton, NJ }\end{array}$ \\
\hline Thiophanate-methyl & Methyl benzimidazole-carbamate & 3336 & 1 & $50 \mathrm{WP}$ & Cleary Chemical Corporation \\
\hline
\end{tabular}

y Fungicide Resistance Action Committee (http://frag.csl.gov.uk/frac_table2.cfm).

${ }^{\mathrm{z}}$ Percentage of active ingredients in commercial products formulated as emulsion in water (EW), water dispersible granules (WDG), wettable powders (WP), in a water soluble pouch (WSP), a soluble concentrate (SC), or a micro-emulsion concentrate (MEC). 
Table 2. Effect of dipping roots of daylily 'Pardon Me' plants in fungicides or sodium hypochlorite on subsequent plant growth and rust development at 6 and 9 weeks after inoculation ${ }^{y}$

\begin{tabular}{lccccc}
\hline & \multicolumn{2}{c}{ Number of leaves/plant } & & \multicolumn{2}{c}{ DSI (\%) $\mathbf{~}^{\mathbf{z}}$} \\
\cline { 2 - 3 } \cline { 5 - 6 } Fungicide a.i. & $\mathbf{6}$ weeks & $\mathbf{9}$ weeks & & $\mathbf{6}$ weeks & $\mathbf{9}$ weeks \\
\hline Azoxystrobin & $8.4 \mathrm{a}$ & 10.0 & & $0.0 \mathrm{c}$ & $0.0 \mathrm{~d}$ \\
Tebuconazole & $6.1 \mathrm{~b}$ & 9.4 & & $16.5 \mathrm{~b}$ & $20.0 \mathrm{c}$ \\
Mancozeb & $8.3 \mathrm{a}$ & 10.0 & & $32.5 \mathrm{ab}$ & $39.9 \mathrm{ab}$ \\
Fludioxonil & $8.5 \mathrm{a}$ & 9.4 & & $37.4 \mathrm{ab}$ & $45.0 \mathrm{ab}$ \\
Thiophanate-methyl & $8.0 \mathrm{a}$ & 9.3 & & $25.2 \mathrm{~b}$ & $32.1 \mathrm{bc}$ \\
Chlorothalonil & $8.1 \mathrm{a}$ & 10.3 & & $27.2 \mathrm{~b}$ & $40.0 \mathrm{ab}$ \\
Sodium hypochlorite & $7.9 \mathrm{a}$ & 10.5 & & $43.5 \mathrm{a}$ & $45.4 \mathrm{ab}$ \\
Nontreated control & $7.8 \mathrm{a}$ & 9.8 & & $44.1 \mathrm{a}$ & $53.0 \mathrm{a}$ \\
LSD & 1.3 & $\mathrm{~ns}$ & & 12.3 & 14.4 \\
\hline
\end{tabular}

${ }^{y}$ Roots of each plant were not dipped (controls) or were dipped in $0.525 \%$ $\mathrm{NaClO}$ or fungicides at $2.4 \mathrm{~g}$ of active ingredient (a.i.) liter ${ }^{-1}$ for $5 \mathrm{~min}$, air dried, and then re-planted in 5.7-liter containers. Means are from eight replicate plants in two trials. Data were analyzed by one-way analysis of variance, and means were separated with Fisher's protected least significant difference (LSD) at $P=0.05$. Means followed by the same letter are not significantly different; $\mathrm{ns}=$ no significant differences among means in this column.

${ }^{z}$ Disease severity index $(\mathrm{DSI})=\left(\sum n_{i} \times i\right) /(5 \times N) \times 100$, where $i$ is rust severity value (0 to 5), $n_{i}$ is the number of leaves with the value of $i$, and $N$ is the number of leaves evaluated on each plant $(13,22)$.
Disease severity ratings on two dates in each year were converted to DSI. Disease ratings from all dates were converted to area under the disease progress curve (AUDPC) to provide an indication of season-long treatment effect (21). Data for DSI and AUDPC were subjected to ANOVA using the general linear models (PROC GLM) procedure. Means were separated by Fisher's protected LSD with $P=0.05$.

\section{Results}

Greenhouse experiments. There were no significant interactions $(P>0.05)$ between fungicide treatment and trial in the two greenhouse experiments; therefore, data from the two trials were combined for analysis.

Root dips in fungicides. Root-dip treatments did not affect plant growth, based on the number of leaves per plant that grew after plants were dipped and replanted, at 6 and 9 weeks after fungicides were applied, with the exception of tebuconazole. Plants drenched with this fungicide had significantly fewer leaves at 6 weeks after treatment but, at 9 weeks after treatment, plant growth was similar to that with other treatments (Table 2). Azoxystrobin, tebuconazole, and thiophanate-methyl dip treatments resulted in significantly lower disease severity 6 and 9 weeks after treatment (Table 2). Lesions were not observed on plants dipped in azoxystrobin, and this treatment was significantly better than all

Table 3. Effects of applying fungicides at three rates as soil drenches on development of rust on container-grown daylily 'Pardon Me' plants in a greenhouse at 6 and 9 weeks after inoculation ${ }^{w}$

\begin{tabular}{|c|c|c|c|c|c|c|}
\hline \multirow[b]{3}{*}{ Fungicide, rate ${ }^{\mathrm{y}}$} & \multicolumn{3}{|c|}{6 weeks } & \multicolumn{3}{|c|}{9 weeks } \\
\hline & \multicolumn{2}{|c|}{ Disease severity index $(\%)^{x}$} & \multirow[b]{2}{*}{$P$ values } & \multicolumn{2}{|c|}{ Disease severity index $(\%)^{x}$} & \multirow[b]{2}{*}{$P$ values } \\
\hline & Individual & Combined & & Individual & Combined & \\
\hline \multicolumn{7}{|l|}{ Azoxystrobin } \\
\hline $0.06^{\circ}$ & $1.8 \mathrm{a}$ & $0.6 \mathrm{C}$ & $\ldots$ & $1.2 \mathrm{a}$ & $0.4 \mathrm{C}$ & $\ldots$ \\
\hline 0.12 & $0.0 \mathrm{~b}$ & $\ldots$ & $\ldots$ & $0.0 \mathrm{~b}$ & $\ldots$ & $\ldots$ \\
\hline 0.24 & $0.0 \mathrm{~b}$ & $\ldots$ & $\ldots$ & $0.0 \mathrm{~b}$ & $\ldots$ & $\ldots$ \\
\hline LSD & 1.1 & $\ldots$ & $\ldots$ & 1.0 & $\ldots$ & $\ldots$ \\
\hline \multicolumn{7}{|l|}{ Fluoxastrobin } \\
\hline 0.06 & 5.4 & $3.8 \mathrm{C}$ & $\ldots$ & 5.5 & $3.9 \mathrm{C}$ & $\ldots$ \\
\hline 0.12 & 2.7 & $\ldots$ & $\ldots$ & 3.5 & $\ldots$ & $\ldots$ \\
\hline 0.24 & 3.2 & $\ldots$ & $\ldots$ & 2.6 & $\ldots$ & $\ldots$ \\
\hline LSD & $\mathrm{ns}$ & $\ldots$ & $\ldots$ & ns & $\ldots$ & $\ldots$ \\
\hline \multicolumn{7}{|l|}{ Tebuconazole } \\
\hline 0.06 & 1.0 & $3.0 \mathrm{C}$ & $\ldots$ & 1.7 & $3.0 \mathrm{C}$ & $\ldots$ \\
\hline 0.12 & 4.5 & $\ldots$ & $\ldots$ & 4.2 & $\ldots$ & $\ldots$ \\
\hline 0.24 & 3.5 & $\ldots$ & $\ldots$ & 3.1 & $\ldots$ & $\ldots$ \\
\hline LSD & ns & $\ldots$ & $\ldots$ & ns & $\ldots$ & $\ldots$ \\
\hline \multicolumn{7}{|l|}{ Myclobutanil } \\
\hline 0.06 & $46.3 \mathrm{a}$ & $17.4 \mathrm{~B}$ & $\ldots$ & $57.5 \mathrm{a}$ & $25.5 \mathrm{~B}$ & $\ldots$ \\
\hline 0.12 & $1.4 \mathrm{~b}$ & $\ldots$ & $\ldots$ & $5.4 \mathrm{~b}$ & $\ldots$ & $\ldots$ \\
\hline 0.24 & $4.4 \mathrm{~b}$ & $\ldots$ & $\ldots$ & $12.1 \mathrm{~b}$ & $\ldots$ & $\ldots$ \\
\hline LSD & 14.2 & $\ldots$ & $\ldots$ & 21.1 & $\ldots$ & $\ldots$ \\
\hline Control & $\ldots$ & $61.6 \mathrm{~A}$ & $\ldots$ & & $68.8 \mathrm{~A}$ & \\
\hline \multicolumn{7}{|l|}{ Two-way ANOVA ${ }^{z}$} \\
\hline Fungicide & $\ldots$ & $\ldots$ & $<0.0001$ & $\ldots$ & $\ldots$ & $<0.0001$ \\
\hline Rate & $\ldots$ & $\ldots$ & $<0.0001$ & $\ldots$ & $\ldots$ & $<0.0001$ \\
\hline Fungicide $\times$ rate & $\ldots$ & $\ldots$ & $<0.0001$ & $\ldots$ & $\ldots$ & $<0.0001$ \\
\hline \multicolumn{7}{|l|}{ One-way ANOVA } \\
\hline Azoxystrobin rate & $\ldots$ & $\ldots$ & 0.0022 & $\ldots$ & $\ldots$ & 0.0274 \\
\hline Fluoxastrobin rate & $\ldots$ & $\ldots$ & 0.1782 & $\ldots$ & $\ldots$ & 0.1164 \\
\hline Tebuconazole rate & $\ldots$ & $\ldots$ & 0.1937 & $\ldots$ & $\ldots$ & 0.4967 \\
\hline Myclobutanil rate & $\ldots$ & $\ldots$ & $<0.0001$ & $\ldots$ & $\ldots$ & 0.0001 \\
\hline
\end{tabular}

${ }^{\text {w }}$ Plants were inoculated with urediniospores of Puccinia hemerocallidis 3 weeks after treatments were applied. Plants were scored for disease 3 and 6 weeks after inoculation, which was 6 and 9 weeks after treatment.

${ }^{\mathrm{x}}$ Disease severity index $=\left(\sum n_{i} \times i\right) /(5 \times N) \times 100$, where $i$ is rust severity value ( 0 to 5$), n_{i}$ is the number of leaves with the value of $i$, and $N$ is the number of leaves evaluated on each plant $(13,22)$. Data are means from eight replicate plants in two trials. Means (for combined and individual treatments) for the main effect of fungicide for all three rates combined and simple effect of rate for each individual fungicide. Means followed by different letters are significantly different and means without any letters are not significantly different (ns) based on Fisher's protected least significant difference (LSD) with $P$ $=0.05$.

y Fungicide active ingredient (a.i.) and drench rate (g a.i./container).

${ }^{\mathrm{z}}$ Data from the two trials were similar and, therefore, were pooled for analysis; data for each time period ( 6 and 9 weeks) were analyzed independently using the Proc GLM procedure of SAS. A two-way analysis of variance (ANOVA) was conducted with all five treatments to identify significant main effects of fungicide and rate and the effects of the fungicide-rate interaction. Because the interaction was significant, one-way ANOVAs were conducted to identify simple rate effects for each fungicide individually. 
other treatments. Plants dipped in chlorothalonil had significantly lower disease severity at 6 weeks post treatment but disease severity on these plants was not significantly different from that on the nontreated control plants at 9 weeks post treatment (Table 2).

Soil drenches with fungicides. All four fungicides significantly and consistently reduced rust development at both 6 and 9 weeks after treatment compared with the nontreated control plants; however, azoxystrobin, fluoxastrobin, and tebuconazole were more effective than myclobutanil (Table 3). There were significant differences in disease severity among the three drench rates but these differences were not uniform for all four fungicides, based on a significant $(P<0.0001)$ fungicide-rate interaction (Table 3$)$. When the effect of drench rate was analyzed for each fungicide independently, disease severity was greater at the low drench rate than at the two higher drench rates for both azoxystrobin and myclobutanil (Table 3). In fact, rust lesions were not observed on plants treated with azoxystrobin at the two higher rates (i.e., 0.12 and $0.24 \mathrm{~g}$ a.i./container). Rate did not affect disease severity on plants treated with fluoxastrobin and tebuconazole; all three rates managed disease equally well (Table 3 ). New leaves on plants drenched with the highest rate of tebuconazole $(0.24 \mathrm{~g}$ a.i./container) were dark green and shorter than leaves on the nontreated control plants. No significant difference in production of new leaves was observed among treatments (data not shown).

Fungicides applied to field-grown plants. Disease pressure was high in both years, with mean disease severity ratings on the nontreated control plants 4.0 or higher on 3 September 2010 and 30 July 2011 (Figs. 1 and 2). In 2010, DSI was calculated on 25

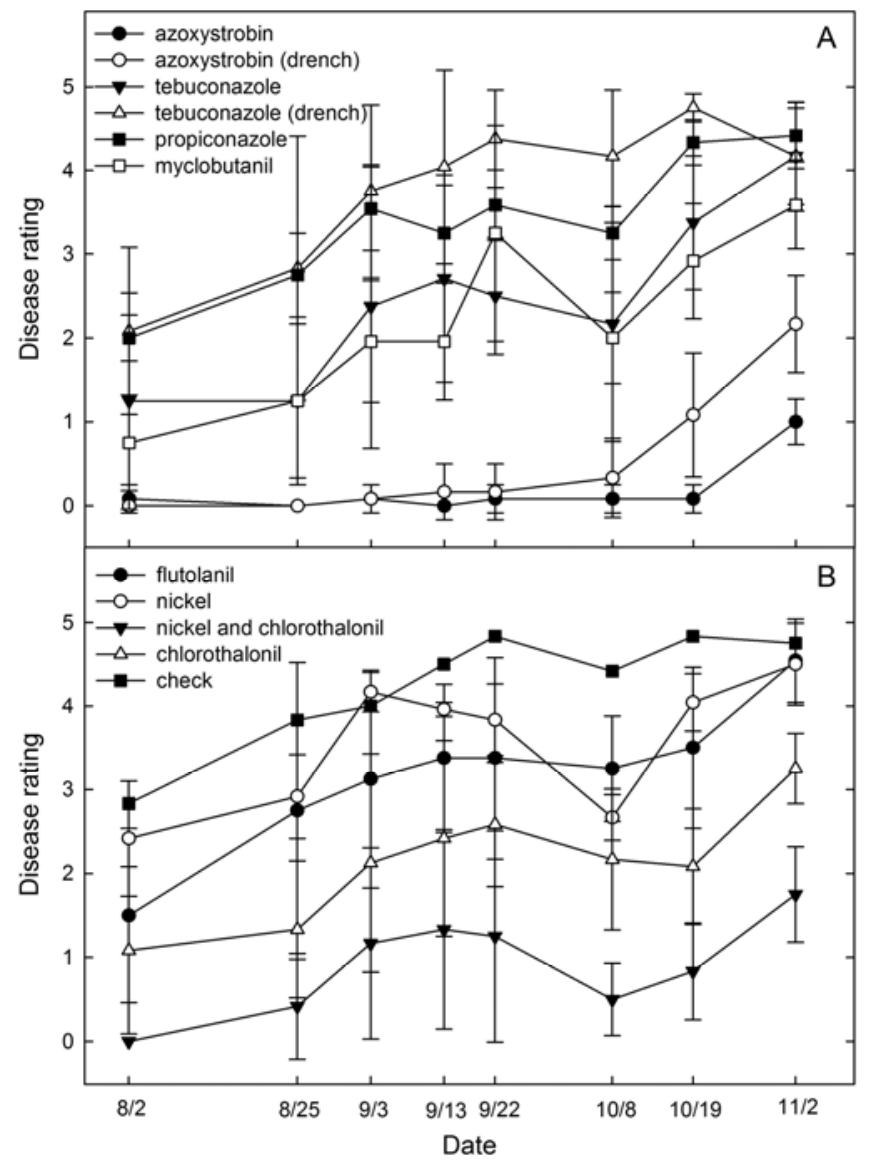

Fig. 1. Effect of fungicide treatments on the development of rust on field grown daylily plants ('Pardon Me') in 2010. Fungicides were applied as a single soil drench on 2 June or as foliar sprays on a 14-day schedule throughout the growing season. Each datum point is the mean disease rating $(0$ to 5 , with $0=$ no lesions and $5=$ many lesions on every leaf) from four blocks of three plants; error bars are standard deviations. A, Quinone outside inhibitor and demethylation inhibitor fungicide treatments are presented separately from $\mathbf{B}$, the control and other treatments to minimize confusion from overlapping disease progress lines.
August (84 days after drenching and 72 days after the first foliar spray) and on 19 October (139 days after drenching and 127 days after the first foliar spray). In 2011, DSI was calculated on 30 July (54 days after drenching and 46 days after the first foliar spray) and on 27 September (113 days after drenching and 105 days after the first foliar spray) (Table 4). Disease pressure was higher early in the season in 2011 (Figs. 1 and 2), and this presumably contributed to fewer treatment differences in 2011 than in 2010 (Table 4). Drench and foliar applications of azoxystrobin provided the best and most consistent disease management across both years. These treatments had the lowest DSI at both rating dates each year, and these values were significantly less than those for most other treatments. In addition, AUDPC for the two azoxystrobin treatments was lower than that for all other treatments in both years and was significantly different from all other values except for the AUDPC value for nickel plus + chlorothalonil in 2010. Disease management with the root drench and foliar spray treatments with azoxystrobin was equally effective, except on 27 September 2011, when plants receiving the foliar sprays had a significantly lower DSI value than plants that were drenched (Table 4). Disease ratings of 1.1 or higher were not observed with the single drench treatment of azoxystrobin until 140 days (19 October) and 99 days (13 September) post treatment in 2010 and 2011, respectively. Foliar sprays with chlorothalonil and chlorothalonil combined with nickel significantly reduced DSI and AUDPC compared with the nontreated control in both years. No other fungicide treatment significantly reduced disease severity compared with the nontreated control in both years of this study.

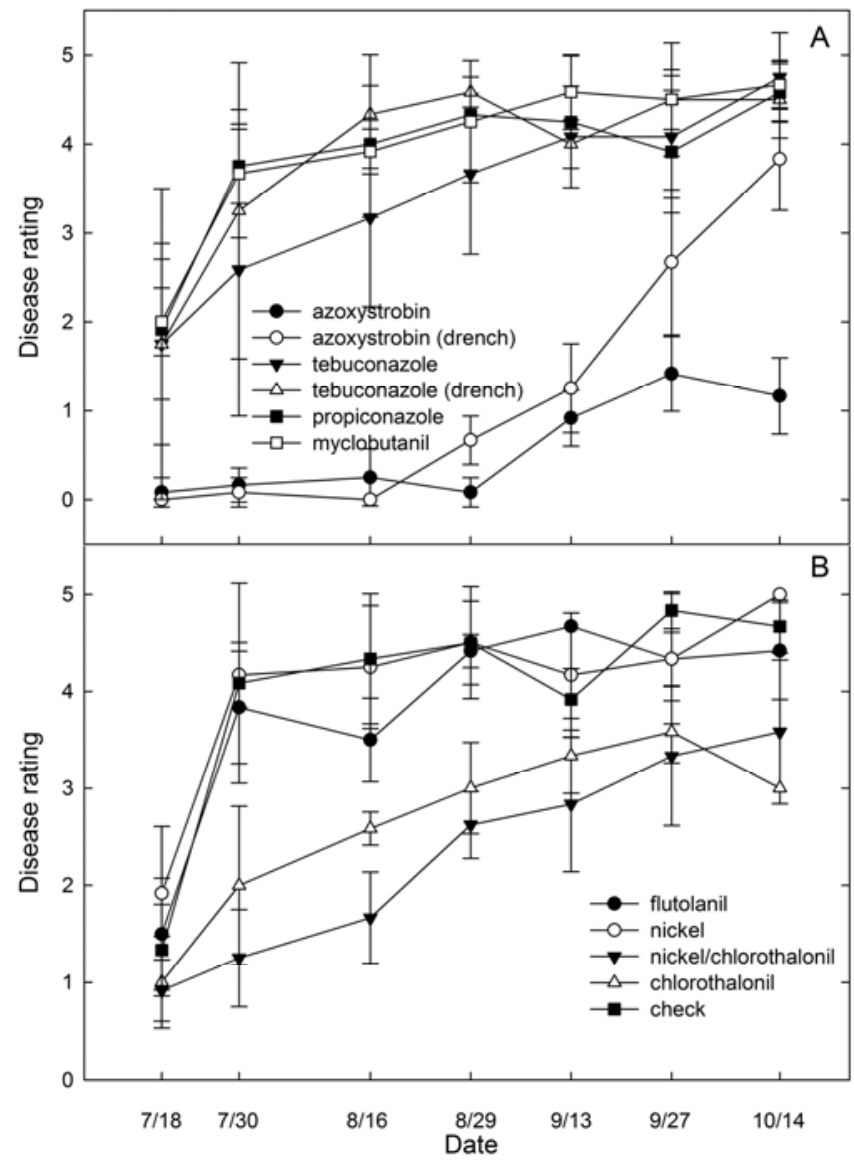

Fig. 2. Effect of fungicide treatments on the development of rust on field grown daylily plants ('Pardon Me') in 2011. Fungicides were applied as a single soil drench on 6 June or as foliar sprays on a 14-day schedule throughout the growing season. Each datum point is the mean disease rating $(0$ to 5 , with $0=$ no lesions and $5=$ many lesions on every leaf) from four blocks of three plants; error bars are standard deviations. A, Quinone outside inhibitor and demethylation inhibitor fungicide treatments are presented separately from B, the control and other treatments to minimize confusion from overlapping disease progress lines. 


\section{Discussion}

Several fungicides have been shown to be effective for managing daylily rust caused by $P$. hemerocallidis $(5,6,14)$. In the present study, foliar applications of azoxystrobin or chlorothalonil to fieldgrown plants significantly reduced disease development over both years. However, alternative methods of fungicide application, such as root dips or soil drenches, would give growers the option of protecting plants with fungicides at critical control points, such as when potentially infected or infested plants have first been received. We found that fungicide dip applications in azoxystrobin, tebuconazole, and thiophanate-methyl and soil drenches with azoxystrobin, fluoxastrobin, and tebuconazole at three rates on container-grown daylily significantly reduced disease development. A single drench of azoxystrobin at the beginning of each field season reduced disease development throughout the growing season. This treatment was as effective as spraying plants with the same fungicide at 14-day intervals throughout the season. The two azoxystrobin treatments gave the best performance of those evaluated in this study. This is the first report of a soil drench application of azoxystrobin being effective for seasonlong management of rust on daylily. This application method may be useful in managing rusts on other crops and should be evaluated.

Drenching the soil when transplanting daylily could benefit daylily growers by providing a significantly long window of protection and, therefore, eliminating several foliar applications of fungicides-potentially saving labor costs and also reducing the risk of introducing rust on new stock. Our field rate of $0.12 \mathrm{~g}$ a.i./plant for a drench application was equal to the amount of fungicide in the three foliar applications of azoxystrobin. Similar AUDPC values were obtained for the single-drench treatment and for six foliar applications of azoxystrobin (with two applications of chlorothalonil). Adequate protection of daylily could be achieved by extending the spray interval for azoxystrobin from 14 to 21 days based on our previous study on fungicide timing (14). However, season-long disease protection from a single drench application could eliminate the necessity of any further fungicide applications.

Drench applications of fungicides concentrate the active ingredient in the root zone of the plants. Although much of the active ingredient is taken up into the plant tissues (2), enough may remain in the soil or substrate to potentially modify the soil microbiota $(1,3)$. Bending et al. (3) assessed the effect of azoxystrobin, chlorothalonil, and tebuconazole on the microbial properties associated with two soil types. The three fungicides did not affect micriobial biomass or bacterial community structure in either soil but did affect some protozoa and fungi (3). Adetutu et al. (1) observed that over $60 \%$ of the azoxystrobin in soils was degraded over 21 days and that, under certain conditions, the fungicide could modify fungal communities. The half-life of azoxystrobin in soils is 7 to 56 days (24), and yet environmental fate studies indicate that azoxystrobin should be moderately persistent, with a half-life of 72 to 164 days (25). Obviously, more research is needed to better understand the impact of fungicides on the soil microbiota.

Root-dip treatments in suspensions of azoxystrobin, tebuconazole, or thiophanate-methyl all significantly reduced lesion development on bare-root daylily plants. All three active ingredients are known to be upwardly mobile through the vascular system in plants to varying degrees $(2,12,17)$. Azoxystrobin is a quinone outside inhibitor (strobilurin) fungicide that is xylem mobile and, thus, able to move into newly expanding or newly emerging leaves (2). Based on our results, it would be prudent for growers, upon receipt of a fresh shipment of daylily plants, to strip away the outer foliage from each plant to eliminate potential rust inoculum and then dip the plant in a fungicide suspension, such as one of those we found to be effective. Daylily plants have upright leaves growing from the crown of the plant. Urediniospores produced on these leaves can settle at the base between adjacent leaves and act as inoculum for new infections as leaves are produced (27). Stripping away outer foliage would reduce potentially infected tissues while the fungicide dip would target any remaining urediniospores or lesions on the crown of the plants. Azoxystrobin, trifloxystrobin, chlorothalonil, mancozeb, and inorganic copper are fungicidal to urediniospores of $P$. hemerocallidis (15).

Flutolanil, myclobutanil, and, to a lesser extent, propiconazole applied as foliar sprays at 14-day intervals throughout the growing season reduced rust development in the first year of the field trials (2010) but not in the second year (2011). Nickel has been reported to reduce daylily rust development (19) but it was not effective in our field trials. Tebuconazole dip and drench treatments of container-grown daylily provided significant reductions in development of lesions by $P$. hemerocallidis. However, this efficacy was not also observed in the field trials. The lack of efficacy of this and other fungicides in our field trials could be due to the continual and high disease pressure present in the field (i.e., constant sources of urediniospores). In addition, selection pressure through the two seasons may have resulted in the establishment of strains of $P$. hemerocallidis with reduced sensitivity to certain active ingredients. Our preliminary assessments of strains obtained from our field study in each year indicate a decreased sensitivity to tebuconazole in 2011 compared with 2010 (W. B. Dong and J. W. Buck, unpublished). A range of sensitivities to the fungicide epoxi-

Table 4. Development of rust on Hemerocallis 'Pardon Me' plants growing in the field that were treated with foliar spray or soil drench applications of fungicides in 2010 and $2011^{\mathrm{w}}$

\begin{tabular}{|c|c|c|c|c|c|c|c|c|}
\hline \multirow[b]{2}{*}{ Active ingredient (a.i.) } & \multirow[b]{2}{*}{ Appl. ${ }^{x}$} & \multirow[b]{2}{*}{$\begin{array}{c}\text { Rate } \\
\text { (g a.i../plant) } \\
\end{array}$} & \multicolumn{3}{|c|}{2010} & \multicolumn{3}{|c|}{2011} \\
\hline & & & $\begin{array}{l}\text { DSI (\%) } \\
25 \text { August }\end{array}$ & $\begin{array}{l}\text { DSI }(\%) \\
19 \text { October }\end{array}$ & $\operatorname{AUDPC}^{\mathrm{z}}$ & $\begin{array}{l}\text { DSI (\%) } \\
\text { 30 July }\end{array}$ & $\begin{array}{c}\text { DSI (\%) } \\
\text { 27 September }\end{array}$ & AUDPC \\
\hline \multirow[t]{2}{*}{ Azoxystrobin } & $\mathrm{D}$ & 0.12 & $0.0 \mathrm{e}$ & $4.5 \mathrm{f}$ & $25.8 \mathrm{e}$ & $0.0 \mathrm{~d}$ & $53.4 \mathrm{e}$ & $96.6 \mathrm{c}$ \\
\hline & $\mathrm{S}$ & 0.04 & $0.0 \mathrm{e}$ & $1.0 \mathrm{f}$ & $10.7 \mathrm{e}$ & $3.3 \mathrm{~cd}$ & $28.3 \mathrm{f}$ & $53.6 \mathrm{c}$ \\
\hline Chlorothalonil & $\mathrm{S}$ & 0.78 & $26.5 \mathrm{~cd}$ & $47.5 \mathrm{e}$ & $188.3 \mathrm{~d}$ & $40.0 \mathrm{~b}$ & $71.7 \mathrm{~cd}$ & $245.2 \mathrm{~b}$ \\
\hline Nickel plus & $\mathrm{S}$ & 0.01 & $58.3 \mathrm{ab}$ & $80.8 \mathrm{abc}$ & $307.8 \mathrm{ab}$ & $83.4 \mathrm{a}$ & $86.7 \mathrm{abc}$ & $365.2 \mathrm{a}$ \\
\hline Nickel plus + chlorothalonil & $\mathrm{S}$ & $0.01+0.78$ & $8.4 \mathrm{de}$ & $16.7 \mathrm{e}$ & $76.7 \mathrm{e}$ & $25.0 \mathrm{bc}$ & $66.7 \mathrm{de}$ & $204.9 \mathrm{~b}$ \\
\hline Flutolanil & $\mathrm{S}$ & 0.02 & $40.0 \mathrm{bc}$ & $70.0 \mathrm{bcd}$ & $278.5 \mathrm{bc}$ & $76.7 \mathrm{a}$ & $86.7 \mathrm{abc}$ & $350.2 \mathrm{a}$ \\
\hline Myclobutanil & $\mathrm{S}$ & 0.01 & $25.0 \mathrm{~cd}$ & $48.5 \mathrm{e}$ & $186.1 \mathrm{~d}$ & $73.4 \mathrm{a}$ & $90.1 \mathrm{ab}$ & $357.5 \mathrm{a}$ \\
\hline Propiconazole & S & 0.01 & $55.0 \mathrm{ab}$ & $86.7 \mathrm{ab}$ & $289.5 \mathrm{~b}$ & $75.0 \mathrm{a}$ & $78.3 \mathrm{bcd}$ & $341.0 \mathrm{a}$ \\
\hline \multirow{2}{*}{ Tebuconazole } & $\mathrm{D}$ & 0.06 & $57.0 \mathrm{ab}$ & $84.0 \mathrm{a}$ & $333.0 \mathrm{ab}$ & $65.0 \mathrm{a}$ & $90.0 \mathrm{ab}$ & $352.9 \mathrm{a}$ \\
\hline & $\mathrm{S}$ & 0.01 & $25.0 \mathrm{~cd}$ & $49.0 \mathrm{~cd}$ & $200.5 \mathrm{~cd}$ & $70.0 \mathrm{a}$ & $86.7 \mathrm{abc}$ & $365.0 \mathrm{a}$ \\
\hline Nontreated control & $\ldots$ & $\ldots$ & $77.0 \mathrm{a}$ & $92.0 \mathrm{a}$ & $381.4 \mathrm{a}$ & $81.7 \mathrm{a}$ & $96.7 \mathrm{a}$ & $366.7 \mathrm{a}$ \\
\hline $\operatorname{LSD}(P=0.05)$ & $\ldots$ & $\ldots$ & 23.2 & 17.1 & 87.5 & 22.4 & 15.9 & 44.8 \\
\hline
\end{tabular}

${ }^{\text {w }}$ Data were analyzed with Fisher's protected least significant difference (LSD) at $P=0.05$. Means followed by the same letter within each column were not significantly different.

${ }^{x}$ Application: fungicides were applied as a single soil drench (D) or every 14 days as a foliar spray (S).

${ }^{\mathrm{y}}$ Disease severity index $(\mathrm{DSI})=\left(\Sigma n_{i} \times i\right) /(5 \times N) \times 100$, where $i$ is rust severity value (0 to 5$), n_{i}$ is the number of plants with the value of $i$, and $N$ is the number of plants evaluated in each treatment $(13,22)$. Data are the means of four replicates for each treatment.

${ }^{\mathrm{z}}$ Area under the disease progress curve (AUDPC) was converted from the rust scale (0 to 5) following the methods of Shaner and Finney (21). 
conazole was reported among a collection of 110 isolates of another rust fungus, $P$. triticina (23).

Exposure of daylily roots to fungicides, in particular to azoxystrobin, by root-dip or soil-drench applications could reduce the risk of introducing or spreading daylily rust on propagative materials or on field-grown plants during season-long maintenance programs. Current fungicide labels do not allow for the drench rates used in the present study and further work is necessary to pursue to possibility of modifying current label restrictions to allow for higher drench rates. Finally, additional studies are necessary to determine whether fungicide dips and drenches are cost effective and can be incorporated into integrated management plans for this disease.

\section{Acknowledgments}

This research was partially supported by a grant from the American Hemerocallis Society. We thank J. Youmans for technical assistance and J. Davis for assistance with statistical analyses.

\section{Literature Cited}

1. Adetutu, E. M., Ball, A. S., and Osborn, A. M. 2008. Azoxystrobin and soil interactions: degradation and impact on soil bacterial and fungal communities. J. Appl. Microbiol. 105:1777-1790.

2. Bartlett, D. W., Clough, J. M., Godwin, J. R., Hall, A. A., Hamer, M., and Parr-Dobrzanski, B. 2002.The strobilurin fungicides. Pest. Manage. Sci. 58:649-662.

3. Bending, G. D., Rodriguez-Cruz, M. S., and Lincoln, D. S. 2007. Fungicide impacts on microbial communities in soils with contrasting management histories. Chemosphere 69:82-88.

4. Buck, J. W., and Ono, Y. 2012. Daylily rust. The Plant Health Instructor. Online publication. doi:10.1094/PHI-I-2012-0516-01

5. Buck, J. W., and Williams-Woodward, J. L. 2003.The effect of fungicides on urediniospore germination and disease development of daylily rust. Crop Prot. 22:135-140.

6. Buck, J. W., and Youmans, J. 2009. Management of daylily rust with Insignia, Pageant or Trinity, 2007. Plant Dis. Manage. Rep. 3:OT017.

7. Dong, W. B., and Buck, J. W. 2011. Effect of light on in vivo urediniospore germination, lesion development and sporulation of Puccinia hemerocallidis on daylily and Puccinia pelargonii-zonalis on geranium. Mycologia 103:1277-1283.

8. Gatlin, F. L. 1999. An Illustrated Guide to Daylilies, 2nd ed. The American Hemerocallis Society, Inc., Kansas City, MO.

9. Gullino, M. L., Minuto, A., Gilardi, G., and Garibaldi, A. 2002. Efficacy of azoxystrobin and other strobilurins against Fusarium wilts of carnation, cyclamen and Paris daisy. Crop Prot. 21:57-61.

10. Hagan, A. K., and Akridge, J. R. 2005. Comparison of fungicide drenches for the control of black spot and Cercospora leaf spot on rose, 2004. Fungic.
Nematicide Tests 60:OT022.

11. Matheron, M. E., and Porchas, M. 2000. Comparison of five fungicides on development of root, crown, and fruit rot of Chile pepper and recovery of Phytophthora capsici from soil. Plant Dis. 84:1038-1043.

12. Mercer, R. T. 1971. Some studies on the systemic activity of the thiophanate fungicides in plants. Pest Manage. Sci. 2:214-218.

13. Moral, J., and Trapero, A. 2009.Assessing the susceptibility of olive cultivars to anthracnose caused by Colletotrichum acutatum. Plant Dis. 93:1028-1036.

14. Mueller, D. S., Jeffers, S. N., and Buck, J. W. 2004. Effect of timing of fungicide applications on development of rusts on daylily, geranium, and sunflower. Plant Dis. 88:657-661.

15. Mueller, D. S., Jeffers, S. N., and Buck, J. W. 2005. Toxicity of fungicides to urediniospores of six rust fungi that occur on ornamental crops. Plant Dis. 89:255-261.

16. Mueller, D. S., Williams-Woodward, J. L., and Buck, J. W. 2003. Resistance of daylily cultivars to the daylily rust pathogen, Puccinia hemerocallidis. HortScience 38:1137-1140.

17. Neumann, S., and Jacob, F. 1995.Principle of uptake and systemic transport of fungicides within the plant. Pages 53-73 in: Modern Selective Fungicides: Properties, Applications, Mechanisms of Action. H. Lyr, ed. Gustav Fisher Verlag, Jena, Germany.

18. Paulus, A. O., Besemer, S., Shibuya, F., and Nelson, J. 1970. Fungicides and dipping interval for control of Fusarium corm rot of Gladiolus. Plant Dis. Rep. 8:689-691.

19. Reilly, C., Crawford, M., and Buck. J. 2005. Nickel suppresses daylily rust, Puccinia hemerocallidis on susceptible daylilies, Hemerocallis in greenhouse and field trials. (Abstr.) Phytopathology 95:S88.

20. Scocco, E. A, Buck, J. W., and Jeffers, S. N. 2012. Drench applications of fungicides for management of geranium rust, 2012. Plant Dis. Manage. Rep. 6:OT018.

21. Shaner, G., and Finnney, R. E. 1977. The effect of nitrogen fertilization on the expression of slow-mildewing resistance in Knox wheat. Phytopathology 67:1051-1056.

22. Song, X. S., Dong, W. B., Min, P., and Song, W. 1994. On the damage and action threshold of northern root-knot nematode on peanut. Acta Phytophylac. Sin. 21:311-315.

23. Stammler, G., Cordero, J., Koch, A., Semar, M., and Schlehuber, S. 2009. Role of the Y134F mutation in cyp51 and overexpression of cyp51 in the sensitivity response of Puccinia triticina to epoxiconazole. Crop Prot. 28:891-897.

24. Tomlin, C. D. S. 2000. The Pesticide Manual, 12th ed. BCPC, Farnham, Surrey, UK.

25. United States Environmental Protection Agency. 1997. Pesticide Fact Sheet: Azoxystrobin. http://www.epa.gov/opp00001/chem_search/reg_actions/reg istration/fs PC-128810 07-Feb-97.pdf

26. Williams-Woodward, J. L., Hennen, J. F., Parda, K. W., and Fowler, J. M. 2001. First report of daylily rust in the United States. Plant Dis. 85:1101.

27. Wise, K. A., Mueller, D. S., and Buck, J. W. 2004. Quarantines and ornamental rusts. APSnet feature article. http://www.apsnet.org/publications/ apsnetfeatures/Documents/2004/QuarantinesOrnamentalRusts.pdf 